
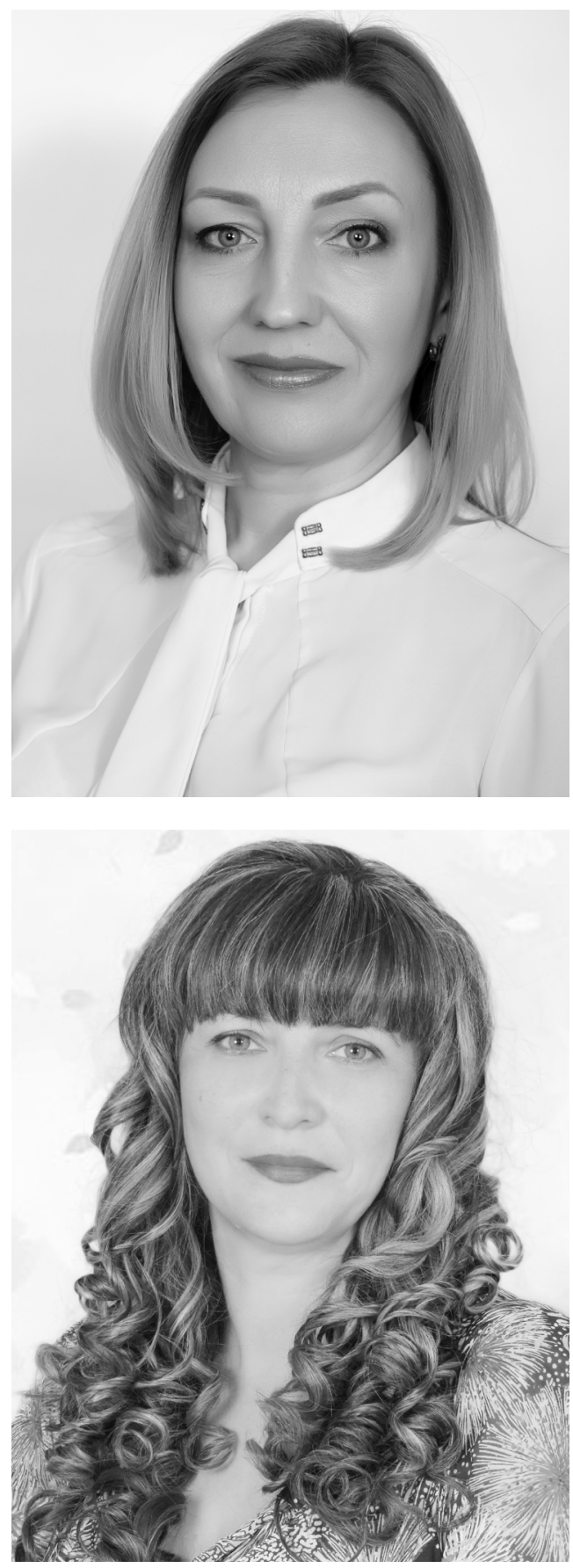

Еиенко Марина Георгиевна,

ассистент кафедры менеджмента, Донбасская национальная академия строительства и архитектуры, 84300, г. Краматорск, ул. Героев Небесной Сотни, 14, тел.: (050) 5891447, e-mail:marinsv@ukr.net

ORCID: 0000-0001-7467-7899

DOI https://doi.org/10.31618/vadnd.v1i13.134
Dolgaleva Olena Vyacheslaviona,

Doctor of Sciences in Public Administration, Professor, Head of the Management Department, Donbas National Academy of Civil Engineering and Architecture, 84300, Kramatorsk, Str. Heroiv Nebesnoi Sotni, 14, tel.: (095) 53354 72, e-mail: elena.dolgaleva21@gmail.com

ORCID: 0000-0002-7281-2046

\section{Долгальова Олена Вячеславівна,}

доктор наук з державного управління, професор, завідувач кафедри менеджменту, Донбаська національна академія будівниитва $і$ архітектури, 84300, м. Краматорсък, вул. Героїв Небесної Сотнi, 14, тел.: (095) 53354 72, e-mail: elena. dolgaleva21@gmail.com

ORCID: 0000-0002-7281-2046

\section{Долгалева Елена Вячеславовна,}

доктор наук по государственному управлению, профессор, заведующий кафедрой менеджмента, Донбасская нащиональная академия строительства и архитектуpы, 84300, г. Краматорск, ул. Героев Небесной Сотни, 14, тел.: (095) 53354 72, e-mail: elena.dolgaleva21@gmail.com ORCID: 0000-0002-7281-2046

\section{Yeshchenko Maryna Georgiiona,}

Assistant of the Management Department, Donbas National Academy of Civil Engineering and Architecture, 84300, Kramatorsk, Str. Heroiv Nebesnoi Sotni, 14, tel.: (050) 5891 447,e-mail:marinsv@ukr.net

ORCID: 0000-0001-7467-7899

\section{Сщенко Марина Георгївна,}

асистент кафедри менеджменту, Донбаська національна академія будівничтва i архітектури, 84300, м. Краматорськ, вул. Героїв Небесної Сотні, 14, тел.: (050) 5891 447, e-mail:marinsv@ukr.net

ORCID:0000-0001-7467-7899 


\title{
THEORETICAL PRINCIPLES OF ORIGIN OF NEGATIVE ECOLOGICAL TERRITORIAL EXTERNALITIES IN THE CONTEXT OF SUSTAINABLE DEVELOPMENT
}

\begin{abstract}
The article examines the territorial type of externalities, which is closely linked to the concept of sustainable development. The modern generation must satisfy its needs without diminishing the opportunities of the following generations. Here the fundamental economic point is the laying of additional external costs of modern generations for the future ones, with the current technological development. The concept of temporal externalities is a new level of awareness of the effect of external negative environmental externalities. The positive experience of the EU countries in creating effective tools for stimulating environmental protection and reducing the complex negative impact on natural ecosystems is considered.

Determined that the implementation of the concept of "risk management" for human health in general is based on a system of tools similar to that of Ukraine [5].

It is noted that, however, the use of these tools in EU countries is based on a mechanism that is significantly different from the domestic one. At the heart of this mechanism is the system of giving the complex environmental permits for industrial installations, which for industrial objects will be determined on the basis of the best available technologies (BATs).

Installed that, the company meets the requirements set by the CEDs, planned to improve the environmental impact indicators, it will be exempted from any financial sanctions (in the form of fines in foreign practice). Such sanctions will arise only if the planned work of the enterprise is not executed and the established limits are not reached.

It is noted that, another methodological approach deals with the analysis of the provision of social and economic system of natural resources based on modelling. Attempts to construct global models of development, taking into account the influence of a set of factors, are widely known in the world practice.

Keywords: sustainable development, external effect, globalization, economic permits, risk management, environment, the best available technology.

\section{ТЕОРЕТИЧНІ ЗАСАДИ ВИНИКНЕННЯ НЕГАТИВНИХ ЕКОЛОГІЧНИХ ТЕРИТОРІАЛЬНИХ ЕКСТЕРНАЛІЙ В КОНТЕКСТІ СТАЛОГО РОЗВИТКУ}

Анотація. Досліджено територіальний тип екстерналій, тісно пов’язаний 3 концепцією сталого розвитку. Сучасне покоління повинно задовольняти свої потреби, не зменшуючи можливості наступних поколінь. Тут принциповим економічним моментом є покладання додаткових екстернальних витрат сучасним поколінням на майбутні, при сформованому технологічному розвитку. Поняття темпоральних екстерналій і є новим рівнем усвідомлення ефекту 
зовнішніх негативних екологічних екстерналій. Розглянуто позитивний досвід країн ЄС у створенні ефективних інструментів стимулювання охорони навколишнього середовища та зниження комплексного негативного впливу на природні екосистеми.

Визначено, що реалізація концепції “управління ризиками” для здоров'я людини в цілому побудована на системі інструментів, аналогічної в Україні. Зазначено, що використання даних інструментів у країнах ЄС спирається на механізм, який значно відрізняється від вітчизняного. Основою даного механізму є система видачі комплексних екологічних дозволів для промислових установок, яка для промислових об’єктів буде визначатися найкращими доступними технологіями (далі НДТ).

Встановлено, якщо підприємство виконує встановлені в КЕД вимоги, заплановані для поліпшення показників впливу на навколишнє середовище, то воно звільняється від будь-яких фінансових санкцій (у вигляді штрафів у зарубіжній практиці). Такі санкції виникають тільки в тому випадку, якщо 3 вини підприємства заплановані роботи не були виконані та встановлені ліміти не були досягнуті.

Зазначено, що інший методологічний підхід розглядає аналіз забезпеченості соціально-економічної системи природними ресурсами на основі моделювання. Світовій практиці широко відомі спроби побудови глобальних моделей розвитку, що враховують вплив комплексу факторів.

Ключові слова: сталий розвиток, екстернальний ефект, глобалізація, економічні дозволи, управління ризиками, навколишнє середовище, найкраща доступна технологія.

\section{ТЕОРЕТИЧЕСКИЕ ОСНОВЫ ВОЗНИКНОВЕНИЯ НЕГАТИВНЫХ ЭКОЛОГИЧЕСКИХ ТЕРРИТОРИАЛЬНЫХ ЭКСТЕРНАЛИЙ В КОНТЕКСТЕ УСТОЙЧИВОГО РАЗВИТИЯ}

Аннотация. Исследованы территориальный тип экстерналий, тесно связанный с концепцией устойчивого развития. Современное поколение должно удовлетворять свои потребности, не уменьшая возможности последующих поколений. Здесь принципиальным экономическим моментом является возложение дополнительных экстернальных расходов современным поколением на будущие, при сложившемся технологическом развитии. Понятие темпоральных экстерналий и является новым уровнем осознания эффекта внешних негативных экологических экстерналий. Рассмотрен положительный опыт стран ЕС в создании эффективных инструментов стимулирования охраны окружающей среды и снижения комплексного негативного воздействия на природные экосистемы.

Определено, что реализация концепции “управление рисками” для здоровья человека в целом построена на системе инструментов, аналогичной в Украине. Отмечено, что использование данных инструментов в странах ЕС опирается на механизм, который значительно отличается от отечественного. В основе данного механизма находится система выдачи комплексных эколо- 
гических разрешений для промышленных установок, которая для промышленных объектов будет определяться наилучшими доступными технологиями (далее НДТ).

Установлено, если предприятие выполняет установленные в КЭД требования, запланированные для улучшения показателей воздействия на окружающую среду, то оно освобождается от любых финансовых санкций (в виде штрафов в зарубежной практике). Такие санкции возникают только в том случае, если по вине предприятия запланированные работы не были выполнены и установлены лимиты не были достигнуты.

Отмечено, что иной методологический подход рассматривает анализ обеспеченности социально-экономической системы природными ресурсами на основе моделирования. Мировой практике широко известны попытки построения глобальных моделей развития, учитывающие влияние комплекса факторов.

Ключевые слова: устойчивое развитие, экстернальный эффект, глобализация, экономические разрешения, управление рисками, окружающая среда, лучшая доступная технология.

Statement of the problem. Ukraine declared the ideology of the sustainable development strategy for the $21^{\text {st }}$ century. Implementation of this strategy requires the appropriate theoretical support. As it is known, the main characteristics of the region are the complexity of social and economic and ecological development; complexity of industrial development; character of industrial and social infrastructures development; the ability to reproduce the conditions for the harmonious development of population living, and so on. The above characteristics are internal. Regarding external influence, the region depends on solving a number of problems associated with the emergence of negative economic territorial externalities and searching effective tools for promoting environmental protection.

The analysis of recent researches. The theoretical foundations of sus- tainable development were covered in the writings of such scholars as: V. H. Vdovych, M. Z. Zhurovskyi, O. V. Kubatko, V. V. Lukianenko, I. O. Mazurina, L. Ts. Maslovska, L. G. Melnyk, T. V. Mohylenets, T. P.Norkina, A. D. Ostapchuk, N. O. Tarkhanova, V. M. Tregobchuk, O. V. Fedun.

Relevance. Analysis of the essence and content of the concept of sustainable development shows that it has brought new aspects into the solution of economic problems as a result of the interaction of the natural environment and social and economic development of human society. Therefore, the study of the relationship of economic, social and environmental problems remains at the moment in the minds of scientists.

The aim of the article. To consider the theoretical principles of the origin of negative ecological territorial externalities and awareness of their effect in order to find effective institutions for 
stimulating environmental protection and reducing the complex negative impact on natural ecosystems.

Presenting the main material. Today the activity in the regional sphere is regulated by the legislation on stimulating the development of regions, on the basis of which the State Strategy for Regional Development for the period up to 2020 is developed and implemented [7]. The content of this strategy determines the problems and proposes constructive directions for their solution in the economic, social and environmental spheres, but does not specify the actions regarding their dependence and the needs of balanced development of these three spheres. Attention is drawn to the desire to balance the economic and environmental spheres in the context of meeting international requirements through the introduction of the quality management system (ISO 9000 standard) and the environmental management system (ISO 14000 standard). The defined state priorities for the development of certain regions for the period up to 2020 include improvement of the ecological situation in general or in certain directions (protection of territories against flooding, overcoming the consequences of ChNPP, etc.) as a separate item for most regions [1].

Analysis of the essence and content of the conception of sustainable development shows that it has introduced new aspects of solving environmental problems as a result of interaction of the natural environment and social and economic development of human society.

Firstly, this is a justification of the relationship of economic, social and environmental problems of the society development.

Secondly, it is a consideration of intergenerational problems, that is, the statement of the need to determine the long-term strategy of human development based on the challenges posed by meeting the needs of present and future generations. In connection with the intergenerational aspect, there is the concept of temporary (temporary, between generations) ecological externalities, which are higher than the territorial level of awareness of the effect of external negative environmental externalities [5].

In the economy the environmental pollution by a manufacturer is usually considered as a negative external effect, when the increase in company profits due to the increase in production turns into harm to the environment, which afflicts some companies and society as a whole.

External effect occurs when the behaviour of one subject directly, and not by means of price changes, affects the welfare of another. External effects appear because of the impossibility or inability to establish the right of ownership of any resource. The consequence of this is the lack of a market for this resource or mechanism which ensure its efficient use. In the presence of an external effect, the market allocation of resources turns out to be ineffective if no action is taken. External effects are called direct, not mediated by the market influence of one economic agent on the activity results of another. These influences can be favorable, in this case they are called positive external effects, or external benefits, and unfavorable, then they 
are called negative external effects, or external costs.

The scholars O. O. Akimov and L. M. Akimova noted that sustainable development is a guided stable social and economic development that does not violate the natural basis, is aimed at survival and the continuous progress of society within the economic capacity of the biosphere [1]. In accordance with the interpretation of the concept of "externalities" we can note that the externalities are the benefit or damage of the third parties who do not participate in the agreement [3].

The temporary type of the externalities is closely linked to the concept of sustainable development. The modern generation must meet its needs, without reducing the ability of future generations to meet their own needs. By generating global environmental problems, exhausting non-renewable resources, contaminating the environment at the present time, modern mankind creates enormous environmental, economic, and social problems for the descendants, narrowing their ability to meet their own needs. Here the fundamental economic point is the laying of additional, external costs of modern generations for the future ones with the current technological development. Thus, exhausting oil in the near future, massive degradation of agricultural land will create enormous energy and food problems for the future, requiring a sharp increase in costs compared with modern ones to meet the very first needs. Technological breakthroughs, achievements of the scientific and technological revolution of contemporaries create the opportunities for reducing costs in the future. For example, the mastering of cheap technologies of energy production (solar) will have a significant economic effect for future generations.

The concept of temporal (intermittent, intergenerational) externalities originally arose in connection with the intergenerational aspect and is a new level of awareness of the effect of the external negative environmental externalities.

In connection with this there are territorial negative ecological externalities, which can be divided into:

1. Global (interstate) externalities. In the scale of the planet, this type of externalities has already generated a number of specific problems associated, first of all, with the transposition of transboundary pollution. Emissions of chemicals into the atmosphere, pollution of rivers and other environmental impacts create significant ecological and economic problems in other countries.

Increasing environmental threats and externalities are causing a series of events or situations in the world that change the potential of development, sovereignty and security of countries, their partner perception in international economic relations. It should be borne in mind that the desire of one state to strengthen environmental safety can lead not only to the improvement of the environment, but also weaken the sense of security in others [2].

Pollution in the United Kingdom as a result of the transport of pollutants leads to the emergence of "dead" lakes in the north of Sweden and the need to allocate the additional costs for environmental protection. These problems are particularly acute in the context of re- 
lations between industrialized and developing countries, when the rich countries have a negative environmental impact on the poor countries, the main polluters and consumers of natural resources, and underdeveloped and poor countries suffer from this. So, in case of global warming and rising sea levels by one meter, the territory of Bangladesh will be reduced by $17 \%$, although the share of this country accounts for only $0,3 \%$ of greenhouse gas emissions. In Egypt, $12 \%$ of the territory might be under water. And the number of examples of such negative environmental impact in the world is becoming more and more. The world community is currently aware of this problem. The special world conventions and agreements, intergovernmental agreements on combating transboundary pollution and obligations of the parties are signed.

2. Intersectional externals. The development of the economic sectors, especially environmental exploitation, causes significant environmental damage to other sectors. In Ukraine, the agrarian sector suffers huge losses. The construction of a cascade of hydropower stations on the Dnipro River (power complex) led to the flooding of high productivity agricultural land. The security zones of power grids and main gas pipelines are accompanied by the loss and degradation of millions of acres of land. All this forces the agriculture to bear additional costs, to develop additional marginal, poorly-developed or remote areas of land. There are also positive intersectional externals. The development of some sectors can have a significant ecological and economic effect in other sectors. This is achieved by an alternative solution to environmen- tal problems, structural adjustment of the economy [6].

3. Interregional externalities. This type of externality is a reduced copy of global externalities, only within a single country. For a country like Ukraine this problem is quite acute. A classic example here may be the Dnipro River, when the regions that are in the upper reaches, with their pollution, create additional costs for water treatment in the "lower" regions.

4. Local externalities. This type of externalities is most well studied in the literature. Typically, an enterprise pollutant is considered in a limited area and external costs of the recipient caused by its activities (other enterprises, population, natural objects, etc.) are analysed.

The countries of the European Union (EU) have gained considerable positive experience in creating effective tools for stimulating environmental protection and reducing the complex negative impact on natural ecosystems.

The foreign system of tools to reduce the negative impact on the environment is based on the concept of "risk management" for human health, which means the establishment of environmental and technical standards based on the existing level of technical and technological development and financial capacity of natural resource companies (and not zero risk, as in the domestic version). Such an approach means considering the problem of reducing the negative impact as a long-term process of reducing environmental risks that can be managed, which allows to set realistic goals and objectives in this direction (both at the national, local and micro levels). 
The implementation of the concept of "risk management" for human health in general is based on a system of tools similar to that of Ukraine [5].

However, the use of these tools in EU countries is based on a mechanism that is significantly different from the domestic one. At the heart of this mechanism is the system of giving the complex environmental permits for industrial installations, which for industrial objects will be determined on the basis of the best available technologies (BATs).

Complex environmental permits (CEDs) in the European Union are authorized by the Directive 96/61/EU on Integrated Pollution Prevention and Control (IPPC Directive).

If the company meets the requirements set by the CEDs, planned to improve the environmental impact indicators, it will be exempted from any financial sanctions (in the form of fines in foreign practice). Such sanctions will arise only if the planned work of the enterprise is not executed and the established limits are not reached.

Another methodological approach deals with the analysis of the provision of social and economic system of natural resources based on modelling. Attempts to construct global models of development, taking into account the influence of a set of factors, are widely known in the world practice [1].

One of them is the "Globesight" model, which combines subsystems such as population (demography), economy (GDP, energy, investments), ecology (use of natural resources). The advantage of the models is the ability to predict the future state, the assessment of the effect of the decisions.
Conclusions from this study. Thus, the mechanism operating in the EU countries is based on a logical prerequisite is a "financial opportunity", and the guides for the best available technology (BAT) are the guarantee for the implementation of environmental conditions and the elimination of errors in making specific management decisions.

\section{REFERENCES}

1. Akimov O. O., Akimova L. M. (2014) Pravove zabezpechennya stalogo rozvitku $\mathrm{v}$ derzhavi ta yiyi regionah. [Legal framework of sustainable development in the state and its regions]. Stalij rozvitok teritorij: Problemi ta shlyahi virishennya: materiali $\mathrm{V}$ mizhnarodnoyi naukovo-praktichnoyi konferenciyi. Dnipropetrovsk, 2014. p. 6.

2. Bohan A. V. (2014) Naukovij koncept ekologichnoyi bezpeki $\mathrm{v}$ mizhnarodnih ekonomichnih vidnosinah [Scientific concept of ecological safety in international economic relations]. Aktualnii problemi ekonomiki. Melitopol, № 12 (162). P. 78-83.

3. Gacalov M. M. (2002) Suchasnij ekonomichnij slovnik-dovidnik [Modern economic dictionary-directory]. Uhta: UGTU. $371 \mathrm{~s}$.

4. Kubatko O. V. (2010) Ekonomikomatematichni pidhodi modelyuvannya procesiv stalogo rozvitku teritorij [Economic-mathematical approaches to modeling processes of sustainable development of territories]. Mehanizm regulyuvannya ekonomiki. Sumi. № 2 . P. 193-199.

5. Norkina T. P. (2011) Strategiya stalogo rozvitku regioniv: resursno-ekologichnij aspekt [Strategy of sustainable development of regions: resourceecological aspect]. Visnik Donbaskoyi nacionalnoyi akademiyi budivnictva i arhitekturi. Makiyivka, Vol. 2 (88). P. 40-44. 
6. Ostapchuk A. D. (2011) Male pidpriyemnictvo - osnova stalogo rozvitku silskih teritorij [Small business is the basis of the sustainable development of rural areas].Naukovij visnik $\mathrm{Na}$ cionalnogo universitetu bioresursiv $\mathrm{i}$ prirodokoristuvannya Ukrayini. Kiyiv. Vol. 163, ch. 2. P. 72-76.

7. Postanova (2014) Kabinetu Ministriv Ukrayini vid 06.08.2014 r. № 385 “Pro zatverdzhennya Derzhavnoyi strategiyi regionalnogo rozvitu na period do 2020 roku" ["On Approval of the State Strategy for Regional Development for the Period till 2020"], available at: http://zakon2.rada.gov.ua/laws/ show/385-2014-n. (Accessed 25 April, 2018).

8. Fedun O. V. (2012) Ekologizaciya mizhnarodnih vidnosin u konteksti stalogo rozvitku [Ecologization of international relations in the context of sustainable development]. Visnik Lvivskogo universitetu. Lviv. Vol. 30. P. 78-86.

\section{СПИСОК ВИКОРИСТАНИХ ДЖЕРЕЛ}

1. Акімов О. О., Акімова Л. М. Правове забезпечення сталого розвитку в державі та їі регіонах. Сталий розвиток територій: Проблеми та шляхи вирішення: матеріали $\mathrm{V}$ міжнар. наук.-практ. конф. (м. Дніпропетровськ, 10-11 жовтня 2014 р.). Дніпропетровськ, 2014. - С. 6.
2. Бохан A. В. Науковий концепт екологічної безпеки в міжнародних економічних відносинах // Актуальні проблеми економіки. - Мелітополь, 2014. - № 12 (162). - С. 78-83.

3. Гацалов М. М. Современный экономический словарь-справочник. Ухта: УГТУ, 2002. - 371 с.

4. Кубатко О. В. Економіко-математичні підходи моделювання процесів сталого розвитку територій. Механізм регулювання економіки. Суми, 2010. - № 2. - С. 193-199.

5. Норкіна Т. П. Стратегія сталого розвитку регіонів: ресурсно-екологічний аспект // Вісн. Донбаської нац. академіі будівництва i архітектури. - Макіївка, 2011. - Вип. 2 (88). C. 40-44.

6. Остапчук А. Д. Мале підприємництво - основа сталого розвитку сільських територій // Наук. вісн. Нац. ун-ту біоресурсів і природокористування України. - К., 2011. Вип. 163, ч. 2. - С. 72-76.

7. Постанова Кабінету Міністрів України “Про затвердження Державної стратегії регіонального розвиту на період до 2020 року" від 06.08.2014 p. № 385 [Електронний pecypc]. - Режим доступу: http:// zakon2.rada.gov.ua/laws/show/3852014-n. (дата звернення: 25.04.2018).

8. Федунь О. В. Екологізація міжнародних відносин у контексті сталого розвитку // Вісн. Львів. ун-ту. Львів, 2012. - Вип. 30. - С. 78-86. 